\title{
流通環境におけるシュンギクの内容成分含有量変化予測モデルの構築
}

\author{
安永円理子 ${ }^{1} \cdot$ 内野敏剛 $^{2} \cdot$ 吉田 敏 ${ }^{1} \cdot$ 田中史彦 ${ }^{2} \cdot$ 筑紫二郎 $^{1}$ \\ ${ }^{1}$ 九州大学生物環境調節センター 812-8581 福岡市東区箱崎 6-10-1 \\ 2 九州大学大学院農学研究院 $812-8581$ 福岡市東区箱崎 6-10-1
}

\section{A Proposed Model to Predict Change in Nutrient Contents of Garland Chrysanthemum (Chrysanthemum coronarium) under Distribution Conditions}

\author{
Eriko YASUNAGA ${ }^{1}$, Toshitaka UCHINO ${ }^{2}$, Satoshi YOSHIDA ${ }^{1}$, Fumihiko TANAKA ${ }^{2}$ and Jiro CHIKUSHI ${ }^{1}$ \\ ${ }^{1}$ Biotron Institute, Kyushu University 6-10-1, Hakozaki, Higashi-ku, Fukuoka, 812-8581, JAPAN \\ ${ }^{2}$ Faculty of Agriculture, Kyushu University 6-10-1, Hakozaki, Higashi-ku, Fukuoka, 812-8581, JAPAN
}

\begin{abstract}
Some researchers have studied the qualitative relationships between changes in nutrient content and respiration rate of postharvest vegetables and fruits, but few have studied these relationships quantitatively. To determine these quantitative variations, we developed a model for predicting the quality changes in vegetables and fruits under simulated distribution conditions. Freshly harvested garland chrysanthemum (Chrysanthemum coronarium) cv. hakata kairyo chuba was sampled. The respiration rate of the vegetable was measured using the flow-through method under simulated distribution conditions. In order to fit the measured rate, we used an improved respiration model including temperature dependence. The model was then extended to predict accumulated respiration. The changes in total sugar and Lascorbic acid of garland chrysanthemum were measured as quality indices using HPLC at arbitrary times under simulated distribution conditions. The model for predicting the relative content of total sugar or L-ascorbic acid during distribution was also developed by combining the proposed model for accumulated respiration with the primary kinetics model. The predictions of the improved respiration model agreed well with the measured values of respiration rates. Content of both total sugar and L-ascorbic acid during the simulated distributions decreased with elapsed time and temperature. The correlation between the integrated values of respiration rate and the relative content of total sugar $\left(R^{2}=0.95\right)$ or L-ascorbic acid $\left(\mathrm{R}^{2}=0.87\right)$ was high. These results show that this model may be useful for understanding quality changes in garland chrysanthemum for any distribution conditions.
\end{abstract}

Keywords: L-ascorbic acid content, quality, respiration rate, temperature, total sugar content

2009 年 7 月 9 日受付

2009 年 7 月 29 日受理

Corresponding author: Eriko Yasunaga (erikoy@agr.kyushu-u.ac.jp)
緒言

近年, 食の安全·安心に対する消費者の意識の向上ととも

に, 青果物を対象としたトレーサビリテイシステムが普及してい

る. 現行のトレーサビリテイシステムでは, 生産情報や出荷情 報が公開されているが, 農水省が行った『野菜の生産流通 
に関する意識・意向調査』 ${ }^{1)}$ の結果, 消費者はそれらの情 報に加え，栄養成分含有量についての情報公開も望んでい ることが明らかになっている.このような状況の下, 消費者ニ ーズに対応した栄養成分含有量情報を付加した新トレーサビ リテイシステムの構築のためには，流通環境に即した青果物 の内容成分含有量変化を定量的に把握する必要がある.す なわち, 流通過程における環境変化の履歴を考慮し, から 青果物の表面・内部破壊を伴わずに含有量変化を把握し得 る数理的評価手法が求められている.

収穫後の青果物は糖や酸などの内容成分を基質とし, 呼 吸を営むことで生命活動を維持しており，呼吸代謝と内容成 分含有量変化との間に密接な関係がある. また, 青果物の 呼吸測定は破壞検査を必要としないため, 内容成分変化の 先駆的指標として注目されてきた. このような背景から,これま でにも青果物の流通中や貯蔵環境に扔ける品質変化予測を 目的として, 呼吸速度予測モデルの構築に関する研究が数 多く行われてきた. 例えば, Uchino et al. ${ }^{2)}$ は時間依存型呼 吸速度予測モデルに対して Arrehenius 型の温度依存性を 適用し, 変温環境下にも対応した温度・時間依存型呼吸速 度予測モデルを提案している. また, 安永ら ${ }^{3)}$ は, 実際の流 通過程をシミュレートした環境下でシュンギクの呼吸速度の経 時変化に対する同モデルの適用性を実証している.

他方, 内容成分含有量と呼吸の関連性に関する研究とし ては, 流通過程を想定し, 変温環境におけるブロッコリーを対 象とした Techavuthiporn et $a l^{4}{ }^{4}$ による研究がある. 彼らは, 呼吸量とアスコルビン酸 (AsA) 含有量の経時変化に対して 種々の実験を行うとともに, 青果物の AsA 含有量の変化を記 述し得る 1 次反応速度式と積算呼吸量から, 変温環境にお ける AsA 含有量の経時変化を予測している. その際, 変温 環境における呼吸速度の予測には, 温度依存性呼吸予測モ デル 5,6) を適用している. このモデルは, Arrhenius 型の温度 依存性の久を考虑し, 青果物の収穫からの時間経過を全く 考慮していない点に改善の余地がある. しかしながら, 種々 の青果物を対象とし, 呼吸量とAsA 含有量の経時変化の関 係を明らかにした研究は依然として少ない，また，青果物の 代表的な内容成分にはAsA 以外にも呼吸基質となる糖類な どもあるため,これらと呼吸量の相関関係を考慮した適切な モデリングを行う必要がある。

本研究では, 福岡市近郊で周年栽培されており, 一般に 軟弱野菜と定義され, その他の青果物に比べ品質劣化速度 が大きいことが知られている葉菜類の 1 つであるシュンギクを 対象として, 流通環境に打ける積算呼吸量とAsA 含有量抒 よび糖含有量の変化特性を把握するともに，それらの関係を 明らかにする.ささらに既存の温度・時間依存性呼吸速度予 測モデル ${ }^{2)}$ と 1 次反応速度論を併用することで流通環境に
おける青果物の内容成分含有量変化を予測する数理モデル の構築を試みた。

\section{材料および方法}

\section{1. 供試材料および温度条件}

実験には, 2007 年 6 月から 12 月に福岡市西区元岡で収 穫されたシュンギク (Chrysanthenum coronarium) 博多改 良中葉'を供試した。供試材料は実験初日に栽培農家の戋 場で採取し, 実験室に保冷輸送後, 品温を実験初期温度に 慣らすため, インキュベー夕内に 3 時間静置した. その後実 験を開始し, 呼吸速度測定ならびに内容成分含有量の測定 を行った。

実験に用いた温度環境は, 流通温度環境調査の結果 ${ }^{7)}$ を基に, 収穫直後から小売店ショーケースへの陳列までの温 度変化の調查值をインキュベー夕内で再現したものである. これを流通温度再現区 (温度条件 1) とした. これに併せ， 小売店ショーケース以外の流通経路においては, 気温が流 通温度再現区よりも $5^{\circ} \mathrm{C}$ 高いものと仮定した仮想流通温度区 (温度条件 2)を設け, 予測モデルの妥当性検証のために用 いた. 対象とした流通経路は, 福岡市内の農家围場から小 売店店頭のショーケースまでの近距離輸送で, その間にシュ ンギクは, 農家保有の予冷庫, JA, 青果市場, 卸売店予冷 庫, 小売店バックヤードを経由している. $23 \sim 27$ 時間経過 時の温度の急増は, 小売店到着後, バックヤードに扔ける調 製作業および待機の時間に生じたものである. すなわち, バッ クヤードの室温はエアコンでのみ調整されており, バックヤード 到着直前の卸売店予冷庫および小売店までの輸送は低温管 理されていたため, バックヤード待機中に急激な温度変化が 生じた. また, 農家圃場, 圃場から JA までの輸送抢よび JA においては, 温度管理がなされていなかったが, それ以外の 流通過程では, 低温管理がなされていたため, 流通環境温 度は徐々に低下している. したがって, 仮想流通温度では, 卸売店予冷庫および小売店ショーケースは同じ温度と仮定 し, それ以外の流通過程の温度を上昇させた。

\section{2. 実験方法}

本研究では, 通気式呼吸速度測定法 ${ }^{3)}$ によって, 流通温 度再現区および仮想流通温度区における呼吸速度の経時 変化を 0.5 時間毎に測定した．流通温度再現区においては 3 回の反復実験を行った. な押, 本研究では, $\mathrm{CO}_{2}$ 排出速度 を呼吸速度とした. 1 回の実験には, シュンギクを $150 \mathrm{~g}$ 供試 した. また, 後の検討で用いる積算呼吸量は呼吸速度を積 算することで算出可能である.

また, 本研究で計測対象とした内容成分は全糖 (グルコー ス, フルクトース, スクロース含有量の総和 ) および L-AsA で, 
Table 1 Analytical condition of HPLC

\begin{tabular}{ll}
\hline \hline & for sugars \\
\hline Column & SCR-101N \\
Column temperature & $40(\mathrm{C})$ \\
Pump & LC-10AD \\
Flow rate of mobile phase & $0.7\left(\mathrm{ml} \mathrm{min}^{-1}\right)$ \\
Mobile phase & Extra-pure water \\
Detector & RID \\
\hline & for L-AsA \\
\hline Column & SCR-101N \\
Column temperature & $40\left({ }^{\circ} \mathrm{C}\right)$ \\
Pump & LC-10AD \\
Flow rate of mobile phase & $1.0\left(\mathrm{ml} \mathrm{min}{ }^{-1}\right)$ \\
Flow rate of reaction phase & $0.5\left(\mathrm{ml} \mathrm{min}{ }^{-1}\right)$ \\
Wave length & $560(\mathrm{~nm})$ \\
& Oxalic acid dihydrate $: 10\left(\mathrm{mM} \mathrm{L}^{-1}(\mathrm{aq})\right)$ \\
Mobile phase & $\mathrm{NaOH}: 15\left(\mathrm{mM} \mathrm{L}^{-1}(\mathrm{aq})\right)$ \\
& EDTA $: 1\left(\mathrm{mM} \mathrm{L}^{-1}(\mathrm{aq})\right)$ \\
Reaction phase & Sodium borohydride : $50\left(\mathrm{mM} \mathrm{L}^{-1}(\mathrm{aq})\right)$ \\
Detector & $\mathrm{NaOH}: 100\left(\mathrm{mM} \mathrm{L} \mathrm{L}^{-1}(\mathrm{aq})\right)$ \\
\hline
\end{tabular}

モデルパラメータ決定のためには, 実験開始後 $0,5,12$, $23,27,51$ および 71 時間経過時に, モデル検証のために は, 実験開始後 $0,23,27,51$ および 71 時間経過時に, 実 験温度に設定されたプログラムインキュベータ内に流通時と同 じ状態で貯蔵していた試料より 5 個体ずつ取り出し, 測定を 行った. また, モデルパラメータ決定のためには 3 反復の繰返 し実験を行い, モデル検証のためには流通温度再現区にお いて 2 反復, 仮想流通温度では 1 回の実験を行った.

全糖含有量測定は, Eguchi and Yoshida の方法 ${ }^{8)}$ に従 い, 下記の手順にて行った. インキュベータより取り出した 5 個体の試料は, それぞれ一旦凍結し, 凍結乾燥器 (東京理 科機器, FD-1) にて凍結乾燥した後に粉砕し, 乾燥粉末試 料を得た. $5 \mathrm{ml}$ のマイクロチューブに乾燥粉末試料約 $1 \mathrm{~g}$, 粉砕ボールおよび超純水 $1 \mathrm{ml}$ を入れ, ボールミル (MM200, レッチェ ) で 5 分間擋拌した後, 溶液に糖を浸透させるため 3 時間静置してから遠心分離を行った. 上澄み液をシャーレ (内径 $22 \mathrm{~mm}$, 高さ $13 \mathrm{~mm}$ ) に移した後, 残椬に超純水を加 え, 撹拌し, 遠心分離し, シャーレに移す操作を 3 回繰り返し た. シャーレに収集した上澄み液をディスポーザブルシリンジで 吸引, $5 \mathrm{ml}$ に定容した後, 孔径 $0.45 \mu \mathrm{m}$ のメンブランフィ ル夕を用いて抽出液を得た. 抽出液は, 高速液体クロマトグラ フ (HPLC) (LC10A，島津製作所) を用いて定量分析した. HPLCの分析条件は, Table 1 に示す.

L-AsA 含有量の測定は, 下記の手順にて行った. 5 個体 の生鮮試料約 $10 \mathrm{~g}$, 試料新鮮重の 3 倍量の $5 \%$ メ夕リン酸 溶液および海砂を適宜それぞれの乳鉢に加え, 乳棒で摩 砕した後, $50 \mathrm{ml}$ のプラスチックチューブに移し, 遠心分離
を行った. 得られた上澄み液を孔径 $0.45 \mu \mathrm{m}$ のメンブラン フィルタを用いてろ過し, 抽出液を得た. 抽出液は, HPLC (LC10AD, 島津製作所) を用いて定量分析した. HPLC の 分析条件は, Table 1 に示す.

\section{3. 内容成分含有量変化予測モデル}

ここではまず, Uchino et $a l^{2}{ }^{2)}$ により提案された呼吸速度予 測モデルについて概説する. その後, 内容成分含有量の経 時変化の実測值および 1 次反応速度論に基づき, 内容成分 含有量変化予測モデルの定式化を試みる.

変温環境下における呼吸速度予測モデルは, 定温環境下 におけるモデルのパラメータに対して Arrhenius 型の温度依 存性を考慮することで定式化が可能となる. これより, 呼吸速 度 $R_{\mathrm{C}}\left[\mathrm{mmol} \mathrm{kg}^{-1} \mathrm{~h}^{-1}\right]$ は次式で与えられる.

$$
R_{\mathrm{C}}=K_{1} \exp \left(\frac{-E_{\mathrm{a}}}{R T}\right)\left\{1+K_{2} \exp \left(-k_{\mathrm{d}} t\right)\right\}
$$

ここに, $K_{1}\left[\mathrm{mmol} \mathrm{kg}^{-1} \mathrm{~h}^{-1}\right]$ および $K_{2}$ [dimensionless] は 酵素の合成・分解に関するパラメー夕を合成したものである. また, $E_{\mathrm{a}}\left[\mathrm{J} \mathrm{mol}^{-1}\right]$ は活性化エネルギー, $R\left[\mathrm{~J} \mathrm{~mol}^{-1} \mathrm{~K}^{-1}\right]$ は 気体定数, $T[\mathrm{~K}]$ は絶対温度, $k_{\mathrm{d}}\left[\mathrm{h}^{-1}\right]$ は分解速度定数, $t$ [h] は実験開始からの経過時間である.

実験開始からの経過時間 $t[\mathrm{~h}]$ における L-AsA および全糖 の相対的な含有量 (相対含有量 ) $C_{\mathrm{A} t}[-]$ および $C_{\mathrm{S} t}[-]$ は, それぞれ次のように与えられる。

$$
C_{\mathrm{At}}=\frac{A_{t}}{\overline{A_{0}}}
$$




$$
C_{\mathrm{S} t}=\frac{S_{t}}{\bar{S}_{0}}
$$

ここに, $A_{t}\left[\mathrm{mg} 100 \mathrm{~g} \mathrm{FW}^{-1}\right]$ および $S_{t}\left[\mathrm{mg} 100 \mathrm{~g} \mathrm{FW}^{-1}\right]$ は 実験開始からの経過時間 $t$ における L-AsA および全糖含有 量である. また, $\bar{A}_{0}\left[\mathrm{mg} 100 \mathrm{~g} \mathrm{FW}^{-1}\right]$ および $\bar{S}_{0}[\mathrm{mg} 100 \mathrm{~g}$ $\left.\mathrm{FW}^{-1}\right]$ は実験開始時の L-AsA および全糖含有量の平均值 である.

Nourian et al. ${ }^{9)}$ は, 貯蔵中の青果物の品質変化が, 1 次 反応速度に従うと記述している. この考え方に基づき, Eq.(2) で表される L-AsA の相対量 $C_{\mathrm{A} t}$ の変化は, 次式のように表現 される.

$$
\frac{d C_{\mathrm{A} t}}{d t}=-k_{\mathrm{A}} C_{\mathrm{A} t}
$$

ここに, $k_{A}\left[\mathrm{~h}^{-1}\right]$ は L-AsA 分解における反応速度定数であ り,ガス環境や温度環境に依存する. Eq.(4)をL-AsA 相対 含有量の初期值を $C_{\mathrm{A} 0}$ として積分すると,

$$
C_{\mathrm{A} t}=C_{\mathrm{A} 0} \exp \left(-k_{\mathrm{A}} t\right)
$$

が得られる. Franck et al. ${ }^{10)}$ が洋ナシを用いて, Villanueva et al. ${ }^{11)}$ はグリーンアスパラガスの, またTechavuthiporn et al. ${ }^{4)}$ はブロッコリーの AsA 含有量の変化を同様の式にて定 式化している.

ここで, L-AsA 含有量の計測には, 破壊試験が必要となる が, 流通環境の温度と収穫からの経過時間との情報から非 破壊的に定量することが可能な指標として, 積算呼吸量を用 い品質変化を予測する Eq.(6) を Techavuthiporn et al. ${ }^{4)}$ の 方法に修正を加え，経験式として提示する.

$$
C_{\mathrm{A} t}=C_{\mathrm{A} 0} \exp \left(\beta_{\mathrm{A}} \int_{0}^{\mathrm{t}} R_{\mathrm{C}} d t\right)
$$

ここに, パラメータ $\beta_{\mathrm{A}}\left[\mathrm{kg} \mathrm{mmol}{ }^{-1}\right]$ は呼吸速度と L-AsA 相 対含有量を関連付けるパラメータである. また, 式 (2)より, $C_{\mathrm{A} 0}=1$ である. したがって, L-AsA 相対量の経時変化は, Eqs.(1) および (2) を Eq.(6) に代入することで, 次式のように 与えられる.

$$
\frac{A_{t}}{\bar{A}_{0}}=\exp \left(\beta_{\mathrm{A}} \int_{0}^{t}\left[K_{1} \exp \left(\frac{-E_{\mathrm{a}}}{\mathrm{R} T}\right)\left\{1+K_{2} \exp \left(-k_{\mathrm{d}} t\right)\right\}\right] d t\right)
$$

全糖に関しても同様の定式化を試み，次式を得る.

$\frac{S_{t}}{\bar{S}_{0}}=\exp \left(\beta_{\mathrm{s}} \int_{0}^{t}\left[K_{1} \exp \left(\frac{-E_{\mathrm{a}}}{\mathrm{R} T}\right)\left\{1+K_{2} \exp \left(-k_{\mathrm{d}} t\right)\right\}\right] d t\right)$
結果および考察

\section{1. 呼吸速度および内容成分含有量の経時変化}

Fig. 1 に流通温度再現区 (温度条件 1) および仮想流通 温度区 (温度条件 2) におけるシュンギクの呼吸速度の実 測值 $\left(R_{\mathrm{C} 1}\right.$ および $\left.R_{\mathrm{C} 2}\right)$ と Eq.(1) による計算值を, また Table 2 に Eq.(1) 中のパラメータおよび二乗平均平方根誤差 (RMSE) の值を示す. 図から, Eq.(1)を用いることで, 実際 の変温環境における呼吸速度の経時変化を精度良く予測し 得ることがわかる.

Fig. 2 に流通温度再現区における収穫時期の異なるシュン ギクの L-AsA 含有量 $\left[\mathrm{mg} 100 \mathrm{~g} \mathrm{FW}^{-1}\right]$ の経時変化を示す. 眓からわかるように, L-AsA 含有量は収穫時期にかかわらず,
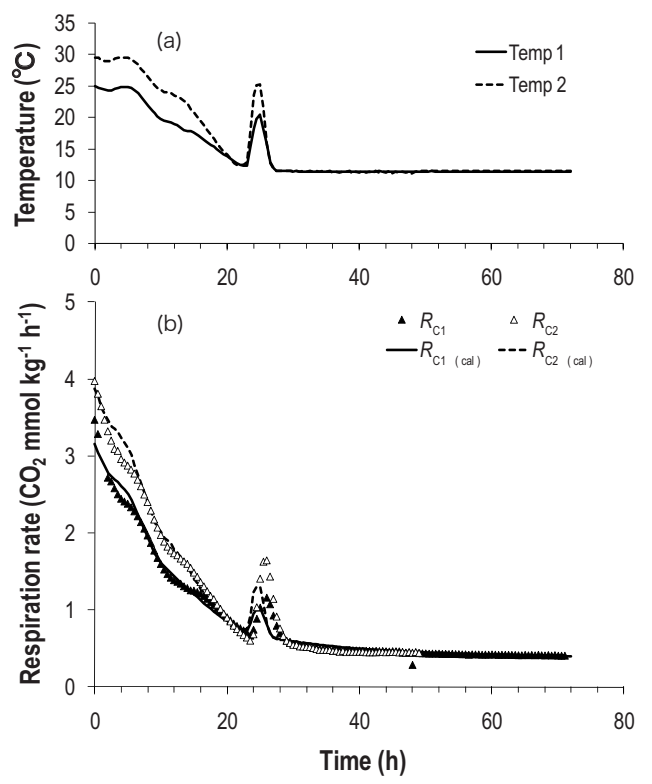

Fig. 1 Time courses of (a) temperature at real distribution temperatures (Temp 1) and hypothetical temperature (Temp 2) and (b) respiration rate of garland chrysanthemum $\left(R_{\mathrm{C} 1}\right.$ and $\left.R_{\mathrm{C} 2}\right)$ stored at Temp 1 and 2. 
Table 2 Model parameters in Eq. (1)

\begin{tabular}{cccccc}
\hline \hline parameter & $\begin{array}{c}K_{1} \\
{\left[\mathrm{mmol} \mathrm{kg}^{-1} \mathrm{~h}^{-1}\right]}\end{array}$ & $\begin{array}{c}E_{\mathrm{a}} \\
{\left[\mathrm{J} \mathrm{mol}^{-1}\right]}\end{array}$ & $\begin{array}{c}K_{2} \\
{[-]}\end{array}$ & $\begin{array}{c}k_{\mathrm{d}} \\
{\left[\mathrm{h}^{-1}\right]}\end{array}$ & $\begin{array}{c}\text { RMSE } \\
{\left[\mathrm{mmol} \mathrm{kg}^{-1} \mathrm{~h}^{-1}\right]}\end{array}$ \\
\hline value & $8 \times 10^{5}$ & $3.4 \times 10^{4}$ & 3.21 & 0.06 & 0.081 \\
\hline
\end{tabular}

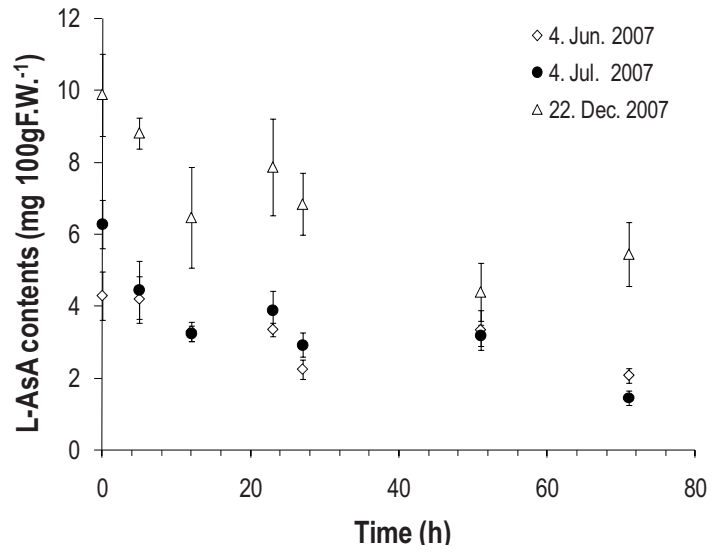

Fig. 2 Time course of L-ascorbic acid contents of garland chrysanthemum at the real distribution temperature (Temp 1). The bars represent the S.E. of the means $(n=5)$.

時間経過および温度環境の変動に伴い減少する傾向が確認 できる. また, 多少の含有量の増減が見られるものの, 急激 な温度変動が生じる $23 \sim 27$ 時間経過前後の值を比較する と,いずれの収穫時期においても減少することが確認された. 貯蔵時の L-AsA 含量が減少するという現象は, ホウレンソ ウを用いた Yamauchi et $a l^{12)}$ の研究やブロッコリーを用いた Techavuthiporn et $a l .{ }^{4}{ }^{4}$ の研究をはじめとし, 数多く報告され ている. 一般に, 貯蔵時もしくは流通中の L-AsA は, DH-AsA に酸化され，その酸化速度は，貯蔵時もしくは流通中の温度 履歴に大きく依存する ${ }^{13)}$. 従って, 本研究に扔ける L-AsA 含 有量の減少も, 流通温度環境および時間経過の影響を受け た結果と考えられる.

Fig. 3 に 2007 年 6 月に収穫したシュンギクのグルコース, フルクトース, スクロースおよび全糖含有量 $\left[\mathrm{mg} 100 \mathrm{~g} \mathrm{FW}^{-1}\right]$ の流通温度再現区における経時変化を示す. 還元糖である グルコース, フルクトースの含有量は, 減少傾向が確認され た. また, L-AsA 含有量と同様に, 多少の含有量の増減が見 られるものの, 急激な温度変動が生じる $23 \sim 27$ 時間経過 前後の值を比較すると, いずれの糖においても減少すること が確認された. グルコースとフルクトースは, 代表的な呼吸基 質として消費されるため, 流通温度環境下の呼吸速度の増 減に伴い，減少したと考えられる，一方，非還元糖であるスク ロース含有量は, 収穫直後から, 微量もしくは検出できない程

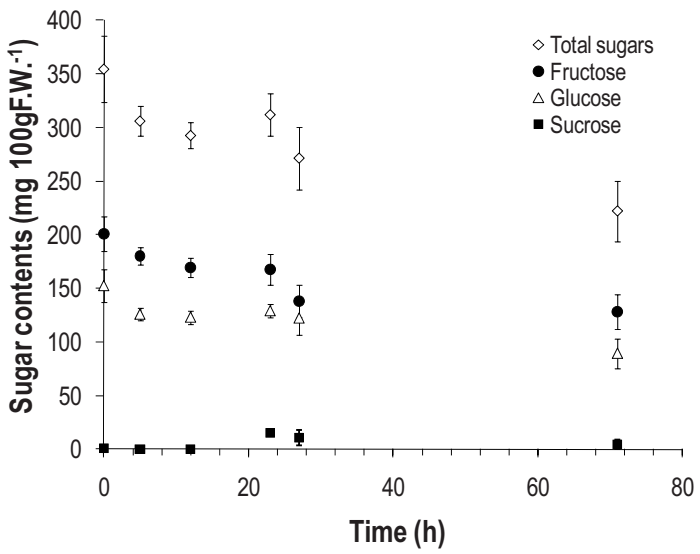

Fig. 3 Time course of glucose, fructose, sucrose and total sugar contents of garland chrysanthemum harvested on $4^{\text {th }}$ June 2007 during the real distribution temperatures (Temp 1). The bars represent the S.E. of the means $(n=5)$.

度であった. 収穫時期の異なる (2007 年 7 月および 2007 年 8 月 ) シュンギクの各糖含有量の構成比はほとんど同じであっ た (図省略) こと, ならびに内容成分予測式の簡素化のた め, 各成分ごとではなく, 全糖含有量として取り扱うこととした.

Fig. 4 に流通温度再現区における収穫時期の異なるシュ ンギクの全糖含有量 $\left[\mathrm{mg} 100 \mathrm{~g} \mathrm{FW}^{-1}\right]$ の経時変化を示す. 全糖含有量は, 高い割合で含まれるグルコースおよびフルタト 一スが呼吸により消費されるため, 経時的に減少した. この現 象は, カットキャベッを対象に貯蔵中の全糖含有量を計測した Nei et al. ${ }^{14)}$ の報告と一致する. しかしながら, 各内容成分の 初期含有量には, 収穫時期ならびに栽培中の環境条件に起 因する差 ${ }^{15,16)}$ が認められるため, 各内容成分含有量変化を 絶対量で議論することは困難である. したがって, 本研究で は各内容成分変化は初期含有量を 1 とした相対含有量変化 として定式化を進めることにした。

\section{2. モデルパラメータの決定}

Figs. 1，2 および 3 に示したデー夕に基づき算出した各成 分の相対含有量 $[-]$ と積算呼吸量 $A R_{\mathrm{C}}\left[\mathrm{mmol} \mathrm{kg}^{-1}\right]$ の関係 を Fig. 5 に示す. 四からわかるように, L-AsA および全糖含 有量の経時変化と積算呼吸量には, それぞれ $\mathrm{R}^{2}=0.87$ お よび $\mathrm{R}^{2}=0.95$ と高い相関があり, Eqs.(7) および (8)の適 用が可能であると考えた. Eq.(1) は Arrehenius 型の温度 


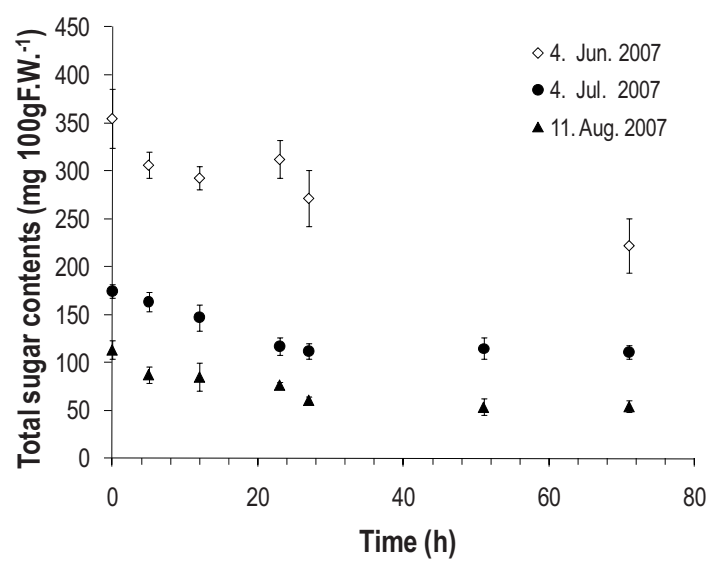

Fig. 4 Time course of total sugar contents of garland chrysanthemum at the real distribution temperature (Temp 1). The bars represent the S.E. of the means $(n=5)$.

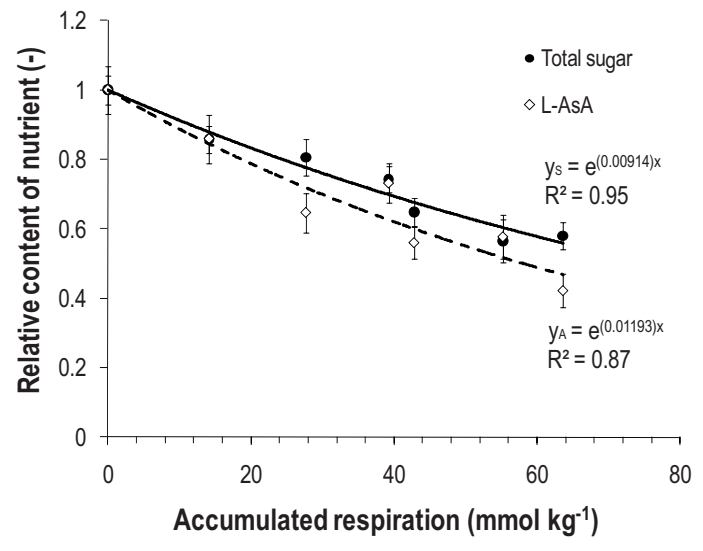

Fig. 5 The relationship between the relative contents of L-ascorbic acid and total sugar and the accumulated respiration of garland chrysanthemum stored at real distribution temperature (Temp 1). The bars represent the S.E. of the means $(n=15)$.

依存性を採用して定式化されており，また既往の研究におい ても内容成分含有量や外観鮮度の反応速度定数に対して Arrehenius 式を導入する方法は良く用いられる ${ }^{13,17,18)}$.この ことからも, Eqs.(7) および (8)のような Arrehenius 型の温度 依存性呼吸速度モデルを用いて内容成分含有量の変化を 記述する方法は，適切である．これにより，積算呼吸量の予 測式と 1 次反応速度式から導出した内容成分含有量の変化 予測モデル (Eqs.(7) および (8)) のパラメー夕は最小自乗法 を用いて決定した。

Fig. 6 に流通温度再現区における L-AsA 相対含有量およ

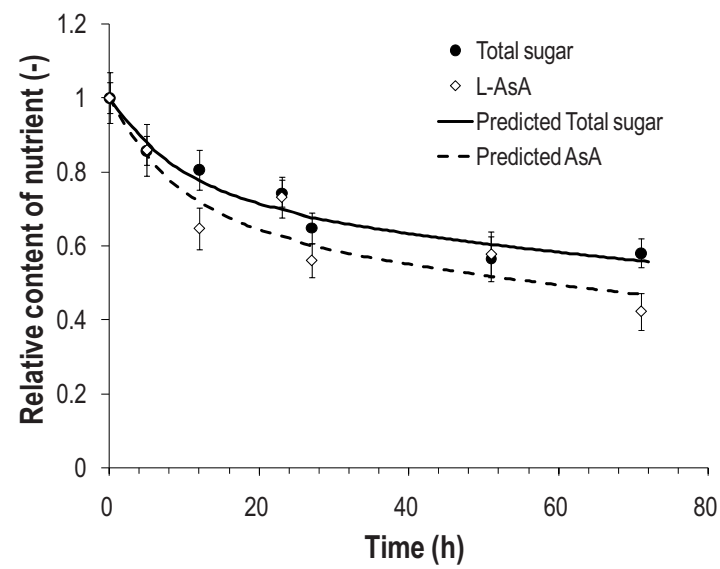

Fig. 6 Time course of relative contents of L-ascorbic acid and total sugar of garland chrysanthemum stored at real distribution temperature (Temp 1). The bars represent the S.E. of the means ( $=15$ ).

び全糖相対含有量の経時変化を示す. ここに, 実測值の誤 差はサンプル数 $n=15$ の標準誤差を表している. また図に は, Eq.(7) ならびに Eq.(8) による予測結果も併せて示してい る.ここに, 積算呼吸量の算出に用いた Eq.(1)のパラメータ は Table 2 のものを採用した. Table 3 に, 各内容成分に対 するパラメータ $\beta_{\mathrm{A}}$ および $\beta_{\mathrm{S}}$ を最小自乗法にて決定した結果 およびモデルの適合度の指標として RMSE を示す. 本研究 で提案しているモデルでは, Fig. 5 に示した積算呼吸量と相 対含有量変化との相関関係のみで式が成立しているため, $23 \sim 27$ 時間経過時のような急激な温度環境変化が生じた 場合でも, 含有量相対值の計算值に表立って表現されないと いう久点があるものの, 流通環境全体を見た場合, 消費者の 手に届く時期 (ここでは, 71 時間経過時) での含有量の予 測值は概ね実測值と一致していた.これらの結果からわかる ように, 提案した内容成分含有量変化予測モデルから算出さ れる予測值と実測值は概ね一致し, 流通環境中の内容成分 含有量の変化を予測するのに提案したモデルが妥当であるこ とが示された.

\section{3. モデルの検証}

次に, 品質予測モデル (Eq.(7) および (8)) のパラメー夕を 決定したデー夕とは異なる, 流通温度再現区 (温度条件 1) ならびに仮想流通温度区 (温度条件 2) において計測した L-AsA 含有量と全糖含有量変化のデータセットを用いて, モ デルの妥当性を検討した. Fig. 7 に示すように, 提案した内 容成分変化予測モデルから算出される予測值と実測值は概 ね一致した，流通温度再現区における L-AsA および全糖含 有量の実測值と予測值との差から算出される RMSE は, そ 


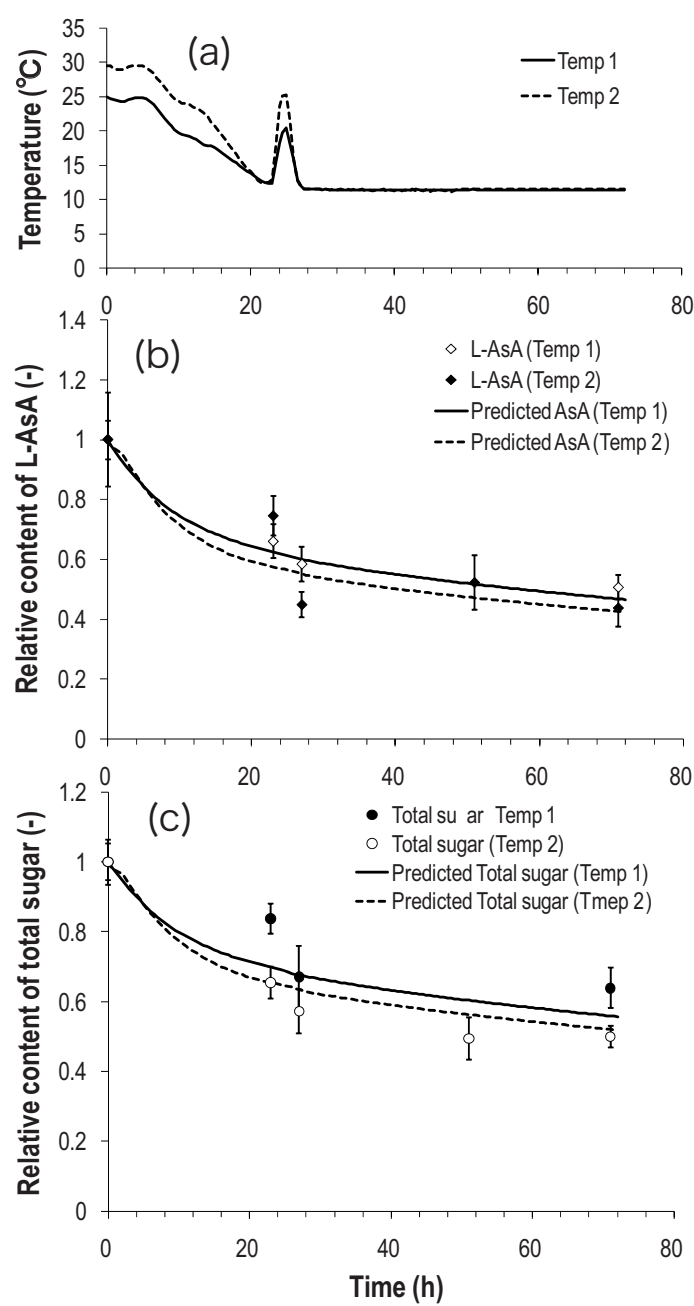

Fig. 7 Time course of (a) temperature at real distribution temperatures (Temp 1) and hypothetical temperature (Temp 2) and (b) relative content of L-ascorbic acid and (c) total sugar of garland chrysanthemum stored at Temp 1 and 2 . The bars represent the S.E. of the means ( $n=10$ at Temp 1 and $\mathrm{n}=5$ at Temp 2).

Table 3 Model parameters in Eq. (7) and (8)

\begin{tabular}{lcc}
\hline \hline & $\beta_{\mathrm{A} \text { or }} \beta_{\mathrm{s}}$ & RMSE \\
{$\left[\mathrm{kg} \mathrm{mmol}^{-1}\right]$} & {$[$ dimensionless] } \\
\hline Ascorbic Acid & $11.93 \times 10^{-3}$ & 0.058 \\
Total sugar & $9.14 \times 10^{-3}$ & 0.029 \\
\hline
\end{tabular}

れぞれ 0.028 および 0.081 であり, 仮想流通温度区における L-AsA および全糖含有量の RMSE は, それぞれ 0.038 およ び 0.092 であった，いずれの温度区，成分においても実用上
問題ない程度の精度で予測可能であると言える. 以上のこと から, シュンギク ‘博多改良中葉”を対象とした流通過程にお いて, 全糖ならびにL-AsAの相対含有量の変化は, Eqs.(7) および (8) によって予測可能であることが示された.

\section{摘 要}

本研究では, 流通温度環境を再現した変温条件における 内容成分含有量変化予測モデルを提案した. 具体的には, 内容成分含有量変化を 1 次反応速度式で表し, 内容成分 は, 積算呼吸速度の関数であることから, 温度・時間依存性 呼吸速度予測モデルにより算出される積算呼吸量を 1 次反 応速度式に代入することで, 全糖および L-AsAの相対含有 量の経時変化を定式化した. 提案したモデルでは, 積算呼 吸量と相対含有量の相関関係のみより定式化しているため, 急激な流通環境変化に付随した含有量の変化を予測するこ とは困難であった. しかしながら, 収穫直後から小売店に至る までの実際の流通温度環境下全体での実測值と予測值を比 較した結果, 各成分含有量の相対含有量変化を実用的な精 度で予測し得ることを示した。

\section{謝辞}

本実験を遂行するにあたり, JA 福岡市春菊部会部会長, 浜地和久氏には, 供試材料の提供において多大なご協力を 頂きました. 福岡大同青果株式会社, 古澤誠一氏には, 流 通環境調査において多大なご協力を頂きました. ここに深く感 謝いたします. また, 本研究は科学研究費補助金 (若手研 究 (B)：20780183)の支援を受けて遂行いたしました. ここに 記して感謝申し上げます。

\section{引用文献}

1）農林水産省.『野菜の生産流通に関する意識・意向調 査』. 2004.

2) Uchino T, Nei D, Hussain S, Hu W. Development of a mathematical model for dependence of respiration rate of fresh produce on temperature and time. Postharvest Biol. Tech. 34: 285-293. 2004.

3) 安永円理子, 内野敏剛, 吉田 敏, 筑紫二郎, 田中史 彦. 流通環境におけるシュンギクの呼吸速度の予測. 植 物環境工学. 21(4); 143-148. 2009.

4) Techavuthiporn C, Nakano K, Maezawa S. Prediction of ascorbic acid content in broccoli using a model equation of respiration. Postharvest Biol. Tech. 47: 387-392. 2008.

5) Fonseca SC, Oliveira FAR, Brecht JK. Modelling 
respiration rate of fresh fruits and vegetables for modified atmosphere packages: a review. J. Food Eng. 52: 99-119. 2002.

6) Iqbal T, Rodrigues FAS, Mahajan PV, Kerry JP. Mathematical modeling of the influence of temperature and gas composition on the respiration rate of shredded carrots. J Food Eng. 91: 325-332. 2009.

7) Yasunaga E, Furue G, Yoshida S, Uchino T. Respiratory characteristic and change in quality of garland chrysanthemum (Chrysanthemum coronarium) under distribution condition. Acta Hortic. 746: 387-392. 2007.

8) Eguchi T, Yoshida S. Effects of application of sucrose and cytokinin to roots on the formation of tuberous roots in sweetpotato (lpomoea batatas (L.) Lam.). Plant Root. 2: 7-13. 2008.

9) Nourian F, Ramaswamy HS, Kushalappa AC. Kinetics of quality change associated with potatoes stored at different temperatures. Lebensm-Wiss. U. -Technol. 36: 49-65. 2003.

10) Franck C, Baetens M, Lammertyn J, Scheerlinck N, Davey MW, Nicolai BM. Ascorbic acid mapping to study core breakdown development in 'Conference' pears. Postharvest Biol. Technol. 30: 133-142. 2003.

11) Villanueva MJ, Tenorio MD, Sagardoy M, Redondo A, Saco MD. Physical, chemical, histological and microbiological changes in fresh green asparagus (Asparagus officinalis, L.) stored in modified atmosphere packaging. Food Chem. 91: 609-619. 2005.

12) Yamauchi $\mathrm{N}$, Watada $\mathrm{AE}$. Ascorbic acid and $\beta$-caroten affect the chlorophyll degradation in stored spicach (Spinacia oleracea L.) leaves. Food Preservation Sci. 24(1): 17-21. 1998.

13) Giannakourou MC, Taoukis PS. Kinetic modeling of vitamin C loss in frozen green vegetables under variable storage conditions. Food Chem. 83: 33-41. 2003.

14) Nei $D$, Uchino $T$, Sakai $N$, Tanaka S. Prediction of sugar consumption in shredded cabbage using a respiratory model. Postharvest Biol. Technol. 41: 56-61. 2006.

15）原忠彦, 因野要一, 中村 隆. シュンギクの品質変 動. 大阪府立農林技術センター研究報告. 33: 8-12. 1997.

16) Conte A, Conversa G, Scrcco C, Brescia I, Laverse $\mathrm{J}$, Elia A, Nobile MAD. Influence of growing periods on the quality of baby spinach leaves at harvest and during storage as minimally processed produce. Postharvest Biol. Technol. 31: 251-261. 2004.

17) Achour M. A new method to assess the quality degradation of food products during storage. J. Food Eng. 75: 560-564. 2006.

18) Corradini MG, Peleg M. Prediction of vitamins loss during non-isothermal heat processes and storage with non-linear kinetics models. Trend in Food Sci. Tech. 50: 190-196. 2008. 